\title{
CHARACTERISTICS OF FAVOURABLE ENVIROMENT FOR DEVELOPMENT OF CREATIVE THOUGT AT LITHUNIA'S COMPREHENSIVE SCHOOL
}

\author{
Rüta Girdzijauskienè, PhD \\ Klaipèda University, Lithuania \\ Daiva Penkauskiene, Ma \\ Mykolas Romeris University, Lithuania
}

\begin{abstract}
The article reveals main characteristics of favourable enviroment for development of creative thought in Lithuanias comprehensive school. The findings are based on the empiric reaserch data, carried out in 2011. 101 educators participated in this reaserch. Positive psychological climate and freedom of action at school have been concidered as the most important factors for the favourable enviroment to develop critical thinking of pupils. Overcrowded curriculum, low learning motivation of pupils have been pointed out as the most negative factors, that influence climate at school.
\end{abstract}

Keywords: Creative thought, education, school enviroment

\section{Introduction}

In the works of contemporary scientists creativity is analyzed as a complex and manifold phenomenon. Some scientists relate creativity to a person's abilities (Cropley, 1999; Simonton, 1999; Weisberg, 1999; et al.), others analyze it as a creative process with its results (Wallas, 1945; Piirto, 1999; Jakobson, 1934; Russ, 1999; Butkienè, Kepalaitè, 1996; et al.). Some other scientists aim at investigating qualities of a creative personality (Jovaiša, 1993; Walberg, Arian, 1999; Cropley, 1999; et al.). Peculiarities of creative thinking have been analyzed probably the most widely (Runco, 1999; Guilford, 1950; Torrance, 1988; MacKinnon, 1967; et al.). One of the most famous researchers of this phenomenon J. P. Guilford (1950) defines creativity as divergent thinking, which is free, flexible, nonstereotypical, rejecting everything what is obvious and usual, and concentrating on various ways of solutions to a problem. E. Torrance (1988) defines creativity as the 
process of thinking characteristic of sensitivity to problems and of information gaps, as well as of subtle sense of disharmony, and etc.

During the late decades creativity has been analyzed in the intricate context of a personality, society, and culture. From the holistic, i.e. the whole, point of view creativity embraces many factors determining creative activity of a person (abilities, skills, personal qualities, motivation, experience in creative activity, and etc.). It is recognized that development of creativity mostly is dependent on the type of surroundings where a person creates and on evaluation of this creation.

Surroundings benevolent for creative thinking are described using different concepts, emphasizing one or the other aspect: psychological climate (Grakauskaite, 2006), creative environment (West, 1990), creative climate (Ekvall, 1997; Dackert, 2001), creative atmosphere (Gebert, 2002), and etc. In the works of scientists it is indicated that while fostering creativity, irrespectively to the sphere of a person's expression, or the type of work, similar indications are typical to benevolent surroundings. Authors present various combinations of features of surroundings. According to G. Ekvall (1997) and I. Dackert (2001), creative surroundings are characteristic of warm atmosphere, sense of commonness and belonging to a group, mutual trust and tolerance, intellectual curiosity and a feeling of freedom, professional competence and intellectual friendship, an opportunity to share ideas and help to those having ideas. Other scientists distinguish the following components of surroundings benevolent for creativity: interpersonal relations and support of colleagues, relation in a group, productivity of activity, character of work of administration, general culture of an organization. German researchers D. Gebert (2002) and E. Krause (2004) point out that creative surroundings are characteristic of open and full of trust atmosphere, fearlessness of changes, encouragement of personal freedom and nonconformism, incitement to change and to improve in professional sphere, orientation towards significant aims, promotion of curiosity and activity. Such features of surroundings benevolent for creativity as significance of activity aims, open communication, conductivity of information, and professional help (Meissner, 1989) are indicated as well.

Analyzing the works of scientists (Ferrari, Cachia, Punie, 2009; Sternberg, Kaufman, Pretz, 2002; Urban, 2003; Vaicekauskienè, 2009; Grakauskaitè, 2006; Cropley, 1999: et al.), who investigated school climate benevolent for development of creativity, a tendency to discuss general culture of school, relations based on mutual trust and respect, stimulation of freedom of activity and independence, cooperation, existence of examples of creative personalities, and appropriate physical environment reveals. Lithuanian psychologist D. Grakauskaitė (2006) exhaustively describes characteristics of a favourable psychological climate: positive attitude 
towards activeness, initiative, creativity, work; tolerance of differences (of a personality, ideas, activity, aims); respect for autonomy of a person; recognition of the right to keep away, to be the leader and have his/her own point of view; freedom to experiment (try, start from the beginning), a possibility to make mistakes and not to be condemned or laughed at; playfulness, humour. The author emphasizes the importance of physical environment for creative thinking as well: abundance of visual details; sights of nature outside the window or compensation of them by indoor plants, pictures; natural decoration materials; prevalence of warm colours or pleasant contrasts.

Even though there are a lot of theoretical discussions about surroundings benevolent for creativity at school, however, empiric research has not been carried out. In Lithuania surroundings benevolent for creativity and creative thinking have been analyzed in the works of some scientists (Grakauskaitè, 2006; Girdzijauskienè, 2009; Vaicekauskienė, 2009).

\section{Research methodology}

Though scientists point out similar characteristics of the surroundings benevolent for creativity, however, they attach different levels of importance to those characteristics. For instance, some scientists (Meissner, 1989) indicate having goals as the most significant feature of surroundings. Others (Ferrari, Cachia, Punie, 2009) emphasize culture of an organization, relations based on mutual trust and respect. Significance of features of the surroundings benevolent for creativity is also dependent on other variables. Therefore, while carrying out the research, problem-based questions were raised: what characteristics of the surroundings benevolent for creative thinking are perceived as the most important ones by Lithuanian teachers? What, in their opinion, are the greatest obstacles to creativity? What should undergo changes in order to design the surroundings benevolent for development of creative thinking at school?

The object of the research - surroundings benevolent for development of creative thinking.

The aim of the research - to reveal the peculiarities of surroundings benevolent for development of creative thinking at a comprehensive school.

The methods of the research: review of pedagogic, psychological literature, and educational documents, a questionnaire to teachers.

Participants of the research. The questionnaire has been answered by 101 teachers working in schools of 5 different regions of Lithuania (including 2 secondary schools, 1 gymnasium, 2 comprehensive schools). Average age of the respondents - 45 years. Vast majority of the research participants were women. Almost three fourths of the respondents have experience of more than 16 years of pedagogic work. Majority of the 
respondents who have answered the questionnaire are primary teachers $(42,6 \%)$, more than a tenth $(13,9 \%)$ teach at 5 th -8 th forms, a fifth $(19,8 \%)$ at 9th - 12th forms, and almost a fourth (23,7\%) at 5th - 12th forms. Sufficiently even distribution of the subjects according to the type of school, place of residence, work record, and forms they teach in, allows to expect objective results of disclosure of surroundings benevolent for creative thinking at Lithuanian schools.

Research instrument. Review of literature references has helped to find the answer to the question what features are characteristic to a creative pupil and to surroundings benevolent for creative thinking. With the aim to reveal the state of surroundings at Lithuanian schools, the subjects have been asked to answer 5 open questions: How do you recognize if a pupil thinks creatively? What surroundings benevolent for creative thinking should be like? What, in your opinion, hinders development of pupils' creative thinking at school? What actions assisting in disclosure of your creative thinking as well as of your pupils' would you expect from school administration, colleagues, pupils? What would you do so that creative thinking of teachers and pupils could manifest itself at full strength? Pedagogues have presented 1-3 answer variants to each question. Analysis of scientific literature has helped to distribute teachers' answers into particular categories and to reveal the features characteristic to surroundings benevolent for creativity at Lithuanian schools.

\section{The results of the research}

With the aim to reveal how pedagogues understand creative thinking, the respondents have been asked to point out how they recognize if a pupil thinks creatively? Pedagogues have presented 240 descriptions (Table 1). Among them in 8 statements features of creative thinking have not been excluded, presenting just general reference to pupils' activity (f.e., 'recognize from works, statements'). One hundred thirty-two characteristics of creative thinking have been presented.

Table 1

Characteristics of a Creatively Thinking Pupil Presented by Pedagogues

\begin{tabular}{|c|c|c|}
\hline $\begin{array}{c}\text { Creative thinking } \\
\text { 144 observations }\end{array}$ & $\begin{array}{c}\text { Thinking abilities, inborn traits } \\
\text { 144 observations }\end{array}$ & $\begin{array}{c}\text { Personal qualities } \\
144 \text { observations }\end{array}$ \\
\hline 70 - originality; & 9 - imagination; & 17 - activeness, learning \\
35 - fluency; & 5 - abilities; & motivation; \\
20 - sagacity; & 4 - intellect. & 13 - thirst for knowledge; \\
15 - flexibility & & 12 - courage ; \\
4 - precision, & & 12 - ability to solve problems; \\
completeness & 10 - breadth of interests; \\
& & 6 - independence, trust. \\
\hline
\end{tabular}


More than two thirds of teachers (70) have pointed out originality (non-traditionalism, novelty, unusualness, singularity) as an exceptional feature of creative thinking. According to the respondents, 'a creatively thinking pupil presents distinctive answers to questions, suggests original variants of solutions to problems', ' the answers are interesting and nonstandard, requiring everybody to think differently'. A lot of attention is devoted to fluency of thinking (35). According to teachers, a creative pupil 'simply shines with ideas', 'quickly finds solutions to a problem', 'constantly proposes various interesting activities to other pupils'.

A fifth of pedagogues (20) who took part in the research emphasize the importance of sagacity: 'a creative pupil notices the things that have been unnoticed, is able to perceive extraordinariness in simple things', 'notices details in the whole or is capable of recreating the whole out of a detail'. In the statements of a sixth of teachers (15) flexibility of thinking is indicated. According to pedagogues, a flexibly thinking pupil 'can consider a problem taking into account various aspects', 'often wonders if anything could be performed differently'. However, only some pedagogues (4) have noticed that a creatively thinking pupil should be able to complete his/her work qualitatively and in time. When describing a creatively thinking pupil, the least attention has been allotted to precision of thinking.

Some teachers relate creative thinking to imagination (9), intellectual abilities (4), skills (5). More than two thirds of respondents (70) attribute features of a creative personality to creative thinking. Most often the following features are mentioned: activeness ('A creatively thinking pupil is active, always wants to organize something, take part in an activity', 'he/she is motivated, does not need to be urged to work, is full of initiative and active in a lesson'), thirst for knowledge ('a creatively thinking pupil is characterisic of curiosity, desire for knowledge', 'he/she is constantly interested in something', 'he/she asks a lot of questions and tells a lot what he/she has found out, seen, or heard'), courage ('he/she is not afraid to make mistakes, to ask questions, to have doubts', 'he/she is not afraid to take risks when creating something new, unusual').

Teachers have been asked to specify what surroundings benevolent for creative thinking should be like. Pedagogues have presented 162 descriptions (Table 2). Among them the characteristics of a favourable psychological climate at school are dominating. It has been noticed that some teachers understand surroundings benevolent for creative thinking as the whole complex of features of physical environment, emphasize concord of things, colours in a classroom. Meanwhile others indicate relationship of the members of school community based on respect and tolerance, their mutual trust as the main features of creative surroundings. Only 2 respondents have 
expressed the opinion that surroundings are not of key importance to a creative personality.

Table 2

Characteristics of Surroundings Benevolent for Creative Thinking Presented by Teachers

\section{5 -Favourable psychological climate at school}

Psychological environment - tolerance and forbearance to those thinking differently', 'this is the environment where a child feels loved, respected, and valued', 'good relationship within a school community'

\section{3 - Freedom of activity, encouragement of creativity in activity}

'There should not be any "frames" how creative works have to be performed, regardless if it is Lithuanian language or other subjects', 'in educational process it would be good to create as many situations requiring creativity as possible', 'nobody has the right to inhibit ideas, on the contrary, help should be provided for their realization'.

\section{9 -Physical environment}

'Activity is performed in warm, full of visual aids classroom. Change of a workplace. Change of surroundings', 'environment has to be safe, cosy so that a pupil could feel free', 'aesthetic environment in a classroom, abundance of visual aids, nontraditional dislocation of desks'.

\section{8 - Provision with aids, financial resources}

'Easily accessible information (library, computer, the Internet), informational literature and textbooks, teaching resources', 'choice of textbooks, abundance of books in the library and in the classroom'.

\section{6 - A possibility to communicate, cooperate}

'Respectful communication and cooperation', 'group work in three or four helps a lot', 'collective work, a company of like-minded people are really important'.

\section{8 - Other}

'Style of upbringing in a family, competence of a school headmaster'.

\section{2 - Of no importance}

'I believe that environment is not the most essential factor to creative thinking'.

When answering the question what hinders development of pupils' creative thinking at school, participants of the research have presented 188 answers (Table 3). Half of pedagogues who took part in the research name overburdened curricula and orientation towards exams, which do not require creative thinking, as the main obstacles. Almost a third of teachers point out that unfavourable psychological climate at school, manifesting itself as intolerance to those thinking differently, as a lack of understanding and support, hinders creativity of both pupils and teachers. Teachers also emphasize indifference of pupils, a lack of confidence in their powers, laziness, and apathy. 


\section{Table 3}

\section{What Hinders Development of Creative Thinking at School?}

\begin{tabular}{|c|}
\hline $49-$ Overloaded curricula \\
\hline $\begin{array}{c}\text { 'Attaching too great importance to knowledge and curricula oriented towards knowledge', } \\
\text { 'programmes are too difficult, pupils have to devote a lot of time to learning, which is not always } \\
\text { related to creativity'. }\end{array}$ \\
\hline 31 - Unfavourable psychological climate at school \\
\hline $\begin{array}{l}\text { 'General atmosphere of school or a classroom is unfavourable, i.e. it does not accept new, } \\
\text { original ideas', 'pupils' self-confidence, fear to be laughed at by friends are disturbing', } \\
\text { 'insufficient tolerance of teachers to differently thinking pupils and colleagues'. }\end{array}$ \\
\hline 31 - Indifference of pupils, a lack of learning motivation \\
\hline $\begin{array}{l}\text { 'Pupils' laziness and apathy', 'low learning motivation of some pupils', 'prejudice towards any } \\
\text { novelties', 'indifference of pupils, distrust in their own powers'. }\end{array}$ \\
\hline 20 - Physical environment, equipment of classrooms, a lack of methodological tools \\
\hline $\begin{array}{c}\text { 'There is a lack of means for realization of ideas, not enough of teaching resources', 'a lack of } \\
\text { teaching resources', }\end{array}$ \\
\hline $13-$ Nothing \\
\hline ‘Nothing hinders. Everyone is happy when an interesting pupil or an event shows up’. \\
\hline 13 - A lack of knowledge, information how to develop pupils' creativity \\
\hline $\begin{array}{l}\text { 'Sometimes professional competencies are inadequate for realization of ideas', 'there is a lack of } \\
\text { knowledge how to stimulate pupils' creative activeness', 'it would be good to know how to } \\
\text { develop pupils' creative thinking most optimally because now this is done intuitively'. }\end{array}$ \\
\hline 11 - Passiveness of teachers, a lack of initiatives \\
\hline $\begin{array}{l}\text { 'Stiff attitude of some colleagues towards innovations', 'conservatism of teachers, unw } \\
\text { to change their style of teaching', 'narrow-mindedness of some teachers'. }\end{array}$ \\
\hline $10-$ Big number of pupils in class \\
\hline $\begin{array}{l}\text { 'Big number of pupils in class, individual approach to every pupil is hardly possible', 'a lot of } \\
\text { pupils in class, there is a lack of time for work with gifted pupils'. }\end{array}$ \\
\hline $10-$ Hard workload of teachers, a lack of time \\
\hline
\end{tabular}

Pedagogues have been asked to consider what actions that could assist in disclosure of both their and their pupils' creative thinking would they expect from school administration, colleagues, pupils. Altogether 546 suggestions have been presented (Table 4). Most statements (209) have been received regarding pupils' participation in activities requiring creative thinking. Teachers tend to name not specific activities, but characteristics of pupils' personalities and of their activity, such as motivation, initiative, activeness, courage to act, and etc., which are significant to creative process.

Three fourths of pedagogues firstly expect support and understanding from their colleagues, almost half - cooperation. Pedagogues consider sharing experience, collegial support as significant factors for development of creativity. According to the participants of the research, from their colleagues they would like to receive 'a more democratic approach, sharing of new ideas and discoveries', 'more joint projects and sincere cooperation'. 
The least number of proposals (151) has been received discussing how school administration could contribute to the development of teachers' and pupils' creativity. However, the same tendency reveals - a need for support and evaluation. Moreover, from school administration pedagogues would expect material resources for implementation of their creative ideas.

Table 4

\section{What do Pedagogues Expect from School Administration, Colleagues,} and Pupils?

\begin{tabular}{|c|c|c|}
\hline $\begin{array}{c}\text { School administration } \\
\text { 151 observations }\end{array}$ & $\begin{array}{c}\text { Collleagues } \\
\text { 186 observations }\end{array}$ & Pupils \\
\hline 0 - support and evaluation; & 77 - support and & 41 - motivation; \\
29- material resources; & understanding; & 26 - initiative; \\
17 - specific measures; & 48 - communication and & 26 - activeness ; \\
5 - communication and & cooperation; & 18 - courage to act; \\
cooperation; & 38 - sharing experience, & 16 - curiosity, thirst for \\
20 - other (respect for a teacher, & help; & knowledge; \\
trust in him/her, more freedom of & 23 - other (initiative, & 9 - originality; \\
activity, and etc.). & openness, desire to work, & 9 - goodwill, tolerance; \\
& and etc.). & 63 -other (ideas, more critical \\
& & thinking, a more interesting activity, \\
& & and etc.). \\
\hline
\end{tabular}

It has been inquired what actions and measures pedagogues would suggest so that creative thinking of teachers and pupils could manifest itself at full strength (Table 5). A fourth of the research participants have voted for editing of curricula, a sixth have considered development of innovations in the sphere of educational methods and educational process to be purposeful, proposed designing teaching/learning environment benevolent for creation, as well as improvement of provision with teaching/learning resources, increased financing for realization of creative ideas.

Table 5

Suggestions of Pedagogues Regarding Development of Creative Thinking

\section{5 - Editing of curricula}

'I would allow editing educational content of subjects', 'would devote more attention to cultural and artistic education of pupils in the teaching plan'.

16 - Innovation in educational methods and in organization of educational process

'Would devote more time to creative group work', 'would pay more attention to the lesson in nontraditional surroundings', 'would look for nontraditional teaching ways, methods'.

\section{5 - Nontraditional environment favourable to creation}

'Schools lack optimism', 'would create tolerant, rich, optimistic atmosphere and environment'. 


\begin{tabular}{|c|}
\hline $\mathbf{1 4}$ - Provision with teaching resources, increased financing \\
\hline $\begin{array}{c}\text { 'It is important to provide everybody with necessary resources and inventory', 'Would } \\
\text { ensure financing of the programmes developing creativity at school'. }\end{array}$ \\
\hline $\begin{array}{c}\text { 12 - Teachers' work extent and salary } \\
\text { 'Would increase teachers' salaries, create the system of motivation', 'Would reduce the } \\
\text { extent of teachers' work'. }\end{array}$ \\
\hline $\mathbf{3 8}$ - Other \\
\hline $\begin{array}{c}\text { 'Would communicate and cooperate more' (7), 'Would decrease the number of pupils in } \\
\text { class' (5), 'Would extend the range of extra-curricular activities' (3), and etc. }\end{array}$ \\
\hline
\end{tabular}

\section{Conclusion}

A person expresses himself/herself creatively only when living in a certain social media, and expression of creativity mostly depends on the surroundings a person is acting in. Analyzing the traits of the surroundings benevolent for creative thinking at school, the importance of school culture is emphasized, i.e. fostering of tolerant environment, stimulation of involvement into activity, recognition of the value of creativity, openness of communication. Psychological climate of school, class atmosphere, relationships of school community members based on trust and respect, personality of a teacher, functional teaching/learning spaces are really important to the development of creativity and creative thinking as well.

Analyzing the data of the empiric research in which 101 pedagogues from 5 Lithuanian schools took part, it has been ascertained that describing surroundings benevolent for creative thinking, pedagogues point out favourable psychological climate of school, freedom of activity and stimulation of creativity in activity, an appropriate physical environment, provision with teaching/learning resources, communication and cooperation as the most significant characteristics.

The greatest obstacles to creative thinking at school are overburdened curricula, unfavourable psychological climate of school, indifference of pupils, and a lack of motivation. In opinion of pedagogues, they would like to receive support and understanding, well-wishing communication and cooperation from their colleagues and school administration, and initiative and higher learning motivation from their pupils, which are necessary for development of teachers' and pupils' creative thinking.

With the aim to foster surroundings benevolent for creative thinking, teachers suggest editing of curricula, encouraging educational innovations, creating of benevolent and open to novelties educational environment at school, provision with new educational resources, decreasing of teachers' workloads.

The research data obtained reveal not only the peculiarities of the surroundings benevolent for creative thinking at Lithuanian schools, but also expose the spheres that require improvement. Fostering of relations based on 
forbearance and respect, as well as organization of school activity grounded on communication and cooperation become particularly urgent.

\section{References:}

Butkienè, G., Kepalaitè, A. (1996). Mokymasis ir asmenybès brendimas. Vilnius: Margi raštai.

Cropley, A. (1999). Education. Encyclopedia of Creativity. ACADEMIC PRESS: California. P. 629-642.

Cropley, A.J. (1999). Definitions of Creativity. Encyclopedia of Creativity, 2. ACADEMIC PRESS: California. P. 511-524.

Dackert, I. (2001). Integration and Creative Experiences after a Merger of Two Organizations within the Social Insurance Service. Lund, Sweden: Lund University, Department of Psychology.

Ekval, G. (1997). Organizational Conditions and Levels of Creativity. Creativity and Innovation Management, 6. P.195-205.

Ferrari, A., Cachia, R., Punie, Y. (2009). Innovation and Creativity in Education and Training in the EU Member States: Fostering Creative Learning and Supporting Innovative Teaching. Literature review on Innovation and Creativity in E\&T in the EU Member States. ICEAC.

Gebert, D. (2002).Leadership and Innovation. Stuttgard: Kohlhammer.

Girdzijauskienè, R. (2009). Mokinių kūrybiškumo ugdymas Lietuvoje. Tarptautine moksline konferencija „Menas. Dizainas. Meninis ugdymas“. Kauno kolegijos J. Vienožinskio menų fakultetas. P.16-21.

Grakauskaitè-Karkockienè, D. (2006). Kürybos psichologijos pagrindai. Vilnius: Logotipas.

Guilford J. P. (1950). Creativity. American Psychologist, 5. P. 444-454.

Jovaiša, L. (2007). Enciklopedinis pedagogikos terminu žodynas. Vilnius: Gimtasis žodis.

Krause, D. E. (2004). Macht und vertrauen in innovationsprozessen: Ein empirischer beitrag zu einer theorie der fuhruhg [Power and Trust in Innovative Processes: An Empirical Contribution to a Theory on Leadership]. Wiesbaden: Gabler.

Mackinonnon, D.W. (1967). The Study of Creative Person: A Metchod and Some Results. Creativity and Learning. Boston: Houghton Mifflin Company. P. 20-29.

Meissner, W. (1989). Innovation und organization. Die initiierung von innovationsprozessen in organisationen [Innovation and Organization. The Introduction of Innovative Processes in Organizations]. Stuttgart: Verlag fur Angewandte Psychologie.

Piirto, J. (1999). A.Survey of Psychological Studies in Creativity. Investigating Creativity in Youth: Research and Methods. Hampton press. P.27-44. 
Runco, M.A. (1999). Self Actualization. Encyclopedia of Creativity. ACADEMIC PRESS: California. P. 533-536.

Russ, S.W. (1999). Emotion/Affect. Encyclopedia of Creativity. ACADEMIC PRESS: California. P. 659-669.

Simonton, D.K. (1999). Creativity from a Historiometric Perspective. Handbook of Creativity. Cambridge: Cambridge University press. P. 48-68.

Sternberg, R. J., Kaufman, J.C., Pretz, J. E. (2002). The Creativity Conundrum: A Propulsion Model of Kinds of Creative Contributions. New York: Psychology Press.

Torrance, E.P. (1988). The Nature of Creativity as Manifest in it's Testing. Cambridge: Cambridge University Press.

Urban, K. (2003). Towards a Componential Model of Creativity. In D. Ambrose, L. M. Cohen,\& A. J. Tannenbaum (Eds.) Creative Intelligence: Toward Theoretic Integration. Cresskill, NJ: Hampton Press. P. 81-112.

Vaicekauskienè, V. (2009). Švietimo problemos analize, Nr.3 (31). P. 12-18. Walberg, H.J., Arian, G. (1999). Distribution of Creativity. Encyclopedia of Creativity. ACADEMIC PRESS: California. P. 573-576.

Wallas, G. (1945). The art of thourt. London: C.A.Watts.

Weisberg, R.W. (1999). Creativity and Knowledge: A Challenge to Theories. Handbook of Creativity. Cambridge: Cambridge University press. P. 114-121.

West, M. A. (1990). The Social Psychology of Innovation in Groups. In M. A. West \& J. L. Farr (Eds.), Innovation and Creativity at Work. Psychological and Organizational Strategies. Chichester: Wiley. P. 309-333. Якобсон, П.М. (1966). Эмоциональная жизнь школника. Москва. 